\title{
Tree diversity and carbon stocks in agroforestry systems in northern Ethiopia
}

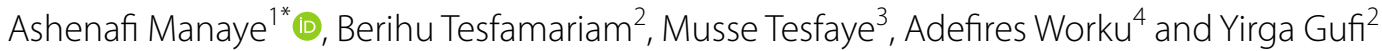

\begin{abstract}
Background: Agroforestry (AF) is an ancient tradition in Ethiopian dryland farming system. Several studies have examined system design, soil fertility management and system interactions, but the biodiversity and mitigation aspects of climate change have received less focus. We assessed the diversity of woody species, biomass carbon (C), and soil organic carbon (SOC) stock associated with indigenous dryland AF practices. A total of 197 smallholder farmers representing four AF practices (home garden, parkland, boundary plantation, and woodlot) from lowland, midland, and highland areas were systematically selected. The inventory of woody species was carried out on each farm's randomly formed plot.

Results: We identified a total of 59 woody species representing 48 genera and 32 families. Shannon diversity index $\left(\mathrm{H}^{\prime}\right)$ was highest in home garden and parkland $\mathrm{AF}$, while woodlots had the highest mean total stock of biomass $\mathrm{C}$ $\left(31 \mathrm{Mg} \mathrm{C} \mathrm{ha}^{-1}\right.$ ). C stocks for smallholding systems (total biomass C and SOC 0-60 cm) ranged from 77-135 Mg ha-1. Total biomass $C$ stocks were significantly correlated with abundance (Spearman $r=0.333 ; p=0.002$ ) but biomass components were not significantly correlated with $\mathrm{H}^{\prime}$. SOC soil depth stock $(0-60 \mathrm{~cm})$ was positively and significantly associated with $H^{\prime}($ Spearman $r=0.291 \& 0.351 ; p<0.01)$.

Conclusions: We report greater species richness in home garden and parkland AF systems than in woodlots. While parkland AF produce lower biomass and SOC stock relative to other AF systems. The strategic use of home gardens and boundary planting can improve tree diversity and carbon storage in Ethiopian dryland ecosystems.
\end{abstract}

Keywords: Boundary planting, Home garden, Parkland, Resilience, Woodlot

\section{Background}

In addition to its global implications, climate change poses a particularly serious threat to developing countries [1-3]. Climate trends directly and indirectly affects both food production and the capacity of natural ecosystems to provide products and services. Sub-Saharan Africa (SSA) has pronounced vulnerabilities linked to endemic poverty and large rural populations whose livelihoods depend on agriculture and ecosystem services that are highly sensitive to rainfall variability $[2,4,5]$.

\footnotetext{
*Correspondence: manayeashenafi@yahoo.com

1 Tigray Institute of Policy Studies, Mekelle, Ethiopia

Full list of author information is available at the end of the article
}

This is a major concern in Ethiopia, where much of the population is chronically food insecure $[4,6,7]$. The northern part of the country (study region) has been identified as particularly climate change vulnerable [8]. Rural populations rely on natural forests for food and income, leading to degradation, and have migrated to marginal and vulnerable areas prone to land loss, drought, pest, and disease outbreaks.

Like several other SSA countries, Ethiopia has a high potential for climate change adaptation and mitigation via agriculture, forestry, and other land use (AFOLU)based pathways, but this requires balancing conflicting social and ecological demands [2].

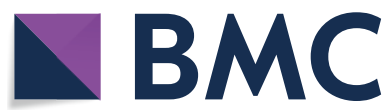

(c) The Author(s) 2021. This article is licensed under a Creative Commons Attribution 4.0 International License, which permits use, sharing, adaptation, distribution and reproduction in any medium or format, as long as you give appropriate credit to the original author(s) and the source, provide a link to the Creative Commons licence, and indicate if changes were made. The images or other third party material in this article are included in the article's Creative Commons licence, unless indicated otherwise in a credit line to the material. If material is not included in the article's Creative Commons licence and your intended use is not permitted by statutory regulation or exceeds the permitted use, you will need to obtain permission directly from the copyright holder. To view a copy of this licence, visit http://creativeco mmons.org/licenses/by/4.0/. The Creative Commons Public Domain Dedication waiver (http://creativecommons.org/publicdomain/ zero/1.0/) applies to the data made available in this article, unless otherwise stated in a credit line to the data. 
Despite a thousand-year history of incorporating trees and shrubs into agricultural land management techniques in Ethiopia [9], however, indigenous, and traditional AF knowledge has been inconsistently formalized and is often excluded from national-scale policy processes. This knowledge is a potentially significant untapped resource: by enhancing carbon stocks and potentially improving agricultural productivity, AF offers a potential solution that could help Ethiopia meet its reforestation and climate-smart agriculture commitments while attending to the needs of vulnerable groups $[9,10]$.

Despite the important contribution of AF systems to climate change adaptation and mitigation $[1,4$, 11-13], not all AF systems are designed to be efficient and widely implemented. Key knowledge gaps include which system works better where, for whom, and under which conditions with climate resilience presenting additional complications [2, 14]. In order to provide an empirical foundation to facilitate the integration of AF into current policy and practices, this study examines how indigenous dryland AF practices in the Tigray region impact on woody plant diversity and carbon storage.

\section{Methods}

\section{Study site}

The study was conducted in three agroecologies (lowland, midland and highland) of the regional state of Tigray, which are geographically located between $12^{\circ}$ and $15^{\circ} \mathrm{N}$ latitude and $36^{\circ} 30^{\prime}-40^{\circ} 30^{\prime} \mathrm{E}$ longitude (Fig. 1).

Table 1 shows the mean annual rainfall, and monthly minimum and maximum temperature of the study area (based on the climate data from years 2000-2014). Except for Tanqu Abergele (Abyi Adi station), both Endamehoni (Maychew station) and Klilte Awlalo (Wukiro station) report a bimodal rain fall pattern. A description of the three agroecologies in the study area is given in Table 1.

\section{Sampling design and methods of data collection}

First, preliminary survey was performed to identify the characteristics of each AF (spatial distribution, their function and structure) and specific sites featuring an AF practices across different agroecologies. A multistage sampling technique was employed to collect the data. The agroecologies were purposively selected to capture both the range of AF practices and

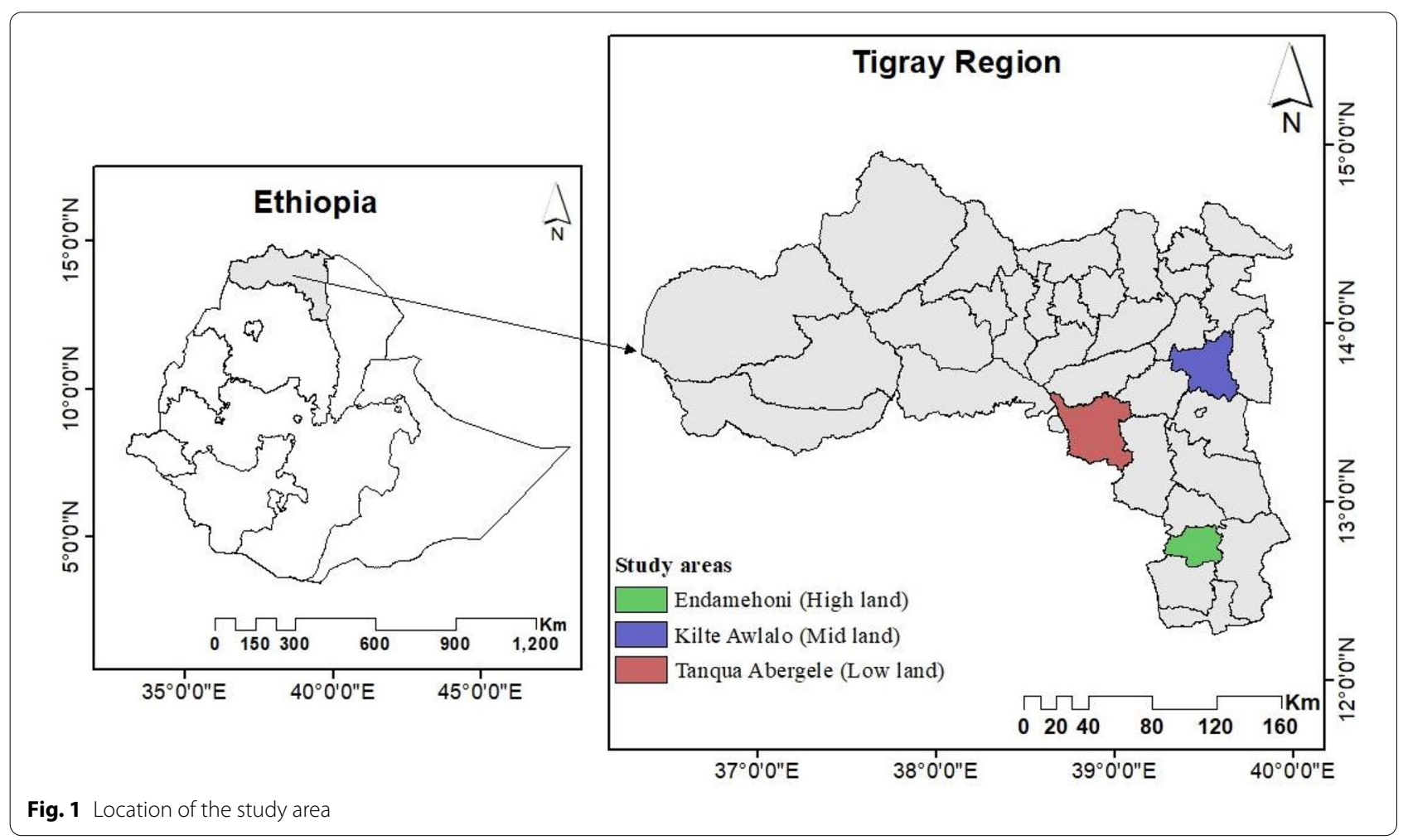


Table 1 Characteristics of the three Agroecology indigenous agroforestry systems in the Tigray Region, Northern Ethiopia

\begin{tabular}{|c|c|c|c|}
\hline Characteristics & Lowland & Midland & Highland \\
\hline Altitude (m a.s.l) & $1300-1500$ & 1930 to 2500 & 1,800 to 3,250 \\
\hline Mean annual rain falls (mm) & 400 to 600 & 397 to 903 & 478 to 956 \\
\hline $\begin{array}{l}\text { Average minimum and maximum } \\
T^{\circ}\left({ }^{\circ} \mathrm{C}\right)\end{array}$ & 14.3 to 29.9 & 11.1 to 28.0 & 10.2 to 22.5 \\
\hline Dominant soil type & Cambisols & Leptosols & Leptosols \\
\hline Textural Class & Sandy loam & Sandy loam & Sandy loam \\
\hline Average $\mathrm{pH} \pm \mathrm{sd}$ & $7.9 \pm 0.4$ & $7.3 \pm 0.5$ & $7.3 \pm 0.4$ \\
\hline Mean size of farms studied (ha) \pm sd & $1.62 \pm 0.76$ & $0.89 \pm 0.78$ & $0.76 \pm 0.49$ \\
\hline Major trees & $\begin{array}{l}\text { Ziziphus spina-christi, Acacia etbaica; } \\
\text { Acacia seyal }\end{array}$ & $\begin{array}{l}\text { Faidherbia albida, Eucalyptus cama- } \\
\text { Idulensis, Faidherbia albida, Acacia } \\
\text { saligna }\end{array}$ & $\begin{array}{l}\text { Eucalyptus globulus, Acacia abys- } \\
\text { sinica, Acacia saligna, Olea a } \\
\text { fricana, Psidium guajava, }\end{array}$ \\
\hline Major food and cash crops & $\begin{array}{l}\text { Zea mays, Sorghum bicolour, Eragros- } \\
\text { tis teff, Linum usitatissimum and } \\
\text { Eleusine coacan }\end{array}$ & $\begin{array}{l}\text { Triticum aestivum, Eragrostis teff, Zea } \\
\text { mays, Eleusine coacana }\end{array}$ & $\begin{array}{l}\text { Hordeum vulgare, Triticum aestivum } \\
\text { and Zea mays }\end{array}$ \\
\hline
\end{tabular}

the agroecological variation across the region, which encompasses highland, lowland, and midland areas.

Systematic random sampling was used to select a total of 197 households (HHs) for tree/shrub inventory; of these, 91 were selected randomly for soil data collection based on their type and number of AF practitioners. Systematic random sampling is a type of probability sampling methods in which sample members from a larger population are selected according to a random starting point but with a fixed, periodic interval. The plot size established randomly for inventory data was $20 \times 20 \mathrm{~m}$ for home garden $\mathrm{AF}$, $50 \times 100 \mathrm{~m}$ for parkland AF, $10 \times 10 \mathrm{~m}$ for woodlot AF and $10 \times 50$ for boundary plantations. Inside each of the larger plot, five nested $1 \times 1 \mathrm{~m}$ (one at the middle and four in the corners) sub-plots were laid for soil sampling. The diameter at breast height (DBH) and height was measured for each tree in all plots. For multi-stemmed woody species such as Ziziphus spina-christ, each stem was measured separately and the equivalent diameter of the plant was calculated as the square root of the sum of diameters of all stems per plant [15]. A total of 273 composite soil samples from depths of $0-20,20-40$ and $40-60 \mathrm{~cm}$ were collected from each plot using soil auger for determination of SOC, and an additional 273 soil samples were collected using soil core sampler for bulk density. The samples were transported to Tigray Agricultural Research Institute, Mekelle Soil Research Center. The soil samples for SOC analysis were airdried, ground, homogenized and sieved with a $2-\mathrm{mm}$ mesh size sieve. The $C$ content of the soil samples was determined using the Walkley-Black method [14]. Bulk density was determined using oven dry method [16].

\section{Terminology}

In this study home garden AF deals with the cultivation of multipurpose and multi-storied trees combined with crop or/and animal husbandry around homestead, Parkland is areas retained with scattered multipurpose trees occur on farmland with farmers preference and protection and there is no grass cover in the cultivated land of the parklands; because the herbaceous plants were weeded in winter, Woodlots are sole stands of tree species planted on farm land or degraded lands to produce fuel wood, construction and land rehabilitation. Boundary plantation denotes trees retained or planted deliberately on the farm boundary.

\section{Data analysis}

Species diversity in different AF practices were determined using species richness, Shannon index of diversity $\left(H^{\prime}\right)$ and Shannon equitability or evenness index (E) [17]. The important value index (IVI) of each species with $\mathrm{DBH} \geq 2.5 \mathrm{~cm}$ was calculated as the sum of its relative abundance, relative dominance, and relative frequency [18].

Above ground biomass (AGB) and below ground biomass (BGB) were estimated using the general allometric equations of [19], which were developed for AF species of Kenya. Tree/shrub biomass was converted 
Table 2 Identified species, genera and families of indigenous AF practices

\begin{tabular}{llcc}
\hline AF practices & Species & Genera & Families \\
\hline Boundary planting & 11 & 8 & 7 \\
Home garden & 23 & 21 & 14 \\
Park land & 47 & 36 & 26 \\
Woodlot & 8 & 6 & 5 \\
\hline
\end{tabular}

Table 3 Household woody species richness, Shannon diversity index $\left(\mathrm{H}^{\prime}\right)$ and evenness in the indigenous AF practices of Tigray Region, Ethiopia

\begin{tabular}{llll}
\hline TAF practices & Richness & H' $^{\prime}$ & Evenness \\
\hline Boundary planting & $2.43 \pm 1.16^{\mathrm{ab}}$ & $0.57 \pm 0.48^{\mathrm{b}}$ & $0.51 \pm 0.37^{\mathrm{b}}$ \\
Home garden & $3.44 \pm 1.55^{\mathrm{b}}$ & $0.93 \pm 0.42^{\mathrm{c}}$ & $0.76 \pm 0.23^{\mathrm{c}}$ \\
Parkland & $3.10 \pm 2.14^{\mathrm{b}}$ & $0.62 \pm 0.49^{\mathrm{b}}$ & $0.51 \pm 0.33^{\mathrm{b}}$ \\
Woodlot & $1.53 \pm 1.00^{\mathrm{a}}$ & $0.20 \pm 0.36^{\mathrm{a}}$ & $0.21 \pm 0.34^{\mathrm{a}}$ \\
p- value & 0.001 & 0.006 & 0.001 \\
\hline
\end{tabular}

Similar letter shows not significant difference and different letters indicate significance differences between AF practices at $p<0.05$

to $\mathrm{C}$ by multiplying the above-ground biomass by 0.5 [20]. SOC stocks $\left(\mathrm{Mg} \mathrm{ha}^{-1}\right)$ were determined following the procedure of [21]. Ecosystem carbon stocks were calculated by summing of biomass and soil $\mathrm{C}$ stocks.

$$
A G B=0.091 \times D B H^{2.472} ; \mathrm{R}^{2}=0.977, \mathrm{n}=72
$$

Where, AGB is the aboveground biomass (dry mass per tree in $\mathrm{kg}$ ) and DBH is diameter at a breast height $(\mathrm{cm})$.

$$
B G B=0.490 \times A G B^{0.923} ; \mathrm{R}^{2}=0.95 ; \mathrm{n}=72
$$

Where, BGB (dry matter per tree in $\mathrm{kg}$ ).

\section{Statistical analysis}

First, all data were checked for normality (using Kolmogorov- Smirnov test) and equality of variance (using Levene's test). The size and variation in tree/ shrub diversity, biomass and SOC stock data were described by mean and standard deviation. One-way ANOVA was performed $(\alpha=0.05)$ to test differences in stand structure and biomass and soil carbon stock between each of the four AF systems. For SOC stock, two-way ANOVA was used since soil depth were considered as study factor together with AF practices. Non-normal data (DBH, height, basal area, richness) were analyzed using non-parametric (Kruskal-Wallis) test. When significant difference was found between the AF practices, a pairwise comparison LSD test was made. SPSS Statistics software (version 21) was used for the statistical analysis [22].

\section{Results}

\section{Characterization of the indigenous AF systems}

The farmers were practicing $61.2 \%$ of Parkland AF followed by $19.4 \%$ rotational woodlots, $12.2 \%$ home garden and $7.1 \%$ boundary plantings as a main AF practices in the study area. Parkland dominated the lowland AF systems, but was uncommon in the highland part of the study area. Eight nine percent of woodlots AF practice were found in the highland agroecology.

\section{Woody species diversity}

These indigenous AF systems contained a total of 59 species, belonging to 48 genera and 32 families (Table 2). Moreover, household woody species diversity, species richness, and evenness significantly differed $(\mathrm{p}<0.05)$ between each indigenous AF practice (Table 3). The Shannon diversity index and evenness value of home garden AF were significantly higher than the other AF practices while the list was

\begin{tabular}{|c|c|c|c|c|}
\hline AF practices & Stem number $\left(\mathrm{ha}^{-1}\right)$ & $\mathrm{DBH}(\mathrm{cm})$ & Height (m) & $\mathrm{BA}\left(\mathrm{m}^{-2} \mathrm{ha}^{-1}\right)$ \\
\hline Boundary planting & $132.14 \pm 114.48^{b}$ & $11.54 \pm 6.37^{\mathrm{a}}$ & $10.79 \pm 4.48^{c}$ & $1.76 \pm 2.11$ \\
\hline Home garden & $187.50 \pm 150.18^{b}$ & $12.46 \pm 8.54^{\mathrm{a}}$ & $8.05 \pm 3.84^{b}$ & $2.89 \pm 1.95$ \\
\hline Park land & $34.67 \pm 26.02^{a}$ & $18.05 \pm 15.28^{b}$ & $5.65 \pm 2.05^{\mathrm{a}}$ & $1.52 \pm 1.59$ \\
\hline Woodlot & $1809 \pm 506.85^{c}$ & $11.01 \pm 6.37^{\mathrm{a}}$ & $11.42 \pm 3.76^{d}$ & $17.08 \pm 13.81$ \\
\hline$p$-value & 0.00 & 0.00 & 0.00 & 0.00 \\
\hline
\end{tabular}

Table 4 Mean $( \pm s d)$ woody species density, dbh and height of agroforestry practices in Tigray Region, Ethiopia

Kruskal Wallis Test ANOVA was conducted to evaluate mean differences between groups and followed by Mann-Whitney U test for multiple comparisons. Similar letter shows not significant difference and different letters indicate significance differences between groups at $\mathrm{p}<0.05$; ns not significant 
Table 5 Mean ( \pm standard deviation; $n=4$ ) biomass carbon, soil carbon (SOC) and agroforestry system total (total biomass plus SOC 0-60 cm) carbon stocks ( $\mathrm{Mg} \mathrm{ha}^{-1}$ ) for each of the four studied agroforestry practices) and results of 1-way ANOVAs (at $\left.a=0.05\right)$

\begin{tabular}{|c|c|c|c|c|c|}
\hline C_Stock & Home garden & Parkland & Woodlot & Boundary planting & $p$ \\
\hline AGB & $5.36 \pm 2.92^{\mathrm{ab}}$ & $5.27 \pm 4.36^{b}$ & $21.43 \pm 8.84^{c}$ & $2.78 \pm 3.55^{\mathrm{a}}$ & 0.000 \\
\hline BGB & $2.43 \pm 1.32^{\mathrm{ab}}$ & $2.38 \pm 1.97^{b}$ & $9.70 \pm 3.40^{c}$ & $1.26 \pm 1.61^{\mathrm{a}}$ & 0.000 \\
\hline$A G B+B G B$ & $7.79 \pm 4.23^{\mathrm{ab}}$ & $7.79 \pm 4.24^{b}$ & $31.12 \pm 12.82^{c}$ & $4.03 \pm 5.15^{\mathrm{a}}$ & 0.000 \\
\hline $5 O C 0-20 \mathrm{~cm}$ & $42.98 \pm 7.90^{b}$ & $29.77 \pm 14.75^{a}$ & $41.43 \pm 15.60^{b}$ & $43.64 \pm 14.44^{b}$ & 0.001 \\
\hline$S O C 20-40 \mathrm{~cm}$ & $33.33 \pm 7.18^{b}$ & $20.06 \pm 9.13^{a}$ & $28.95 \pm 11.78^{b}$ & $34.95 \pm 10.17^{b}$ & 0.000 \\
\hline $\mathrm{SOC} 40-60 \mathrm{~cm}$ & $28.05 \pm 6.92^{\mathrm{ab}}$ & $21.85 \pm 13.48^{a}$ & $26.57 \pm 10.29 \mathrm{ab}$ & $33.78 \pm 14.75^{b}$ & 0.014 \\
\hline $\mathrm{sOC} 0-60 \mathrm{~cm}$ & $108.81 \pm 27.70^{b}$ & $71.69 \pm 26.33^{a}$ & $96.95 \pm 31.16^{b}$ & $112.74 \pm 32.58^{b}$ & 0.000 \\
\hline
\end{tabular}

Similar letter shows not significant difference and different letters indicate significance differences between AF practices at $\mathrm{p}<0.05$

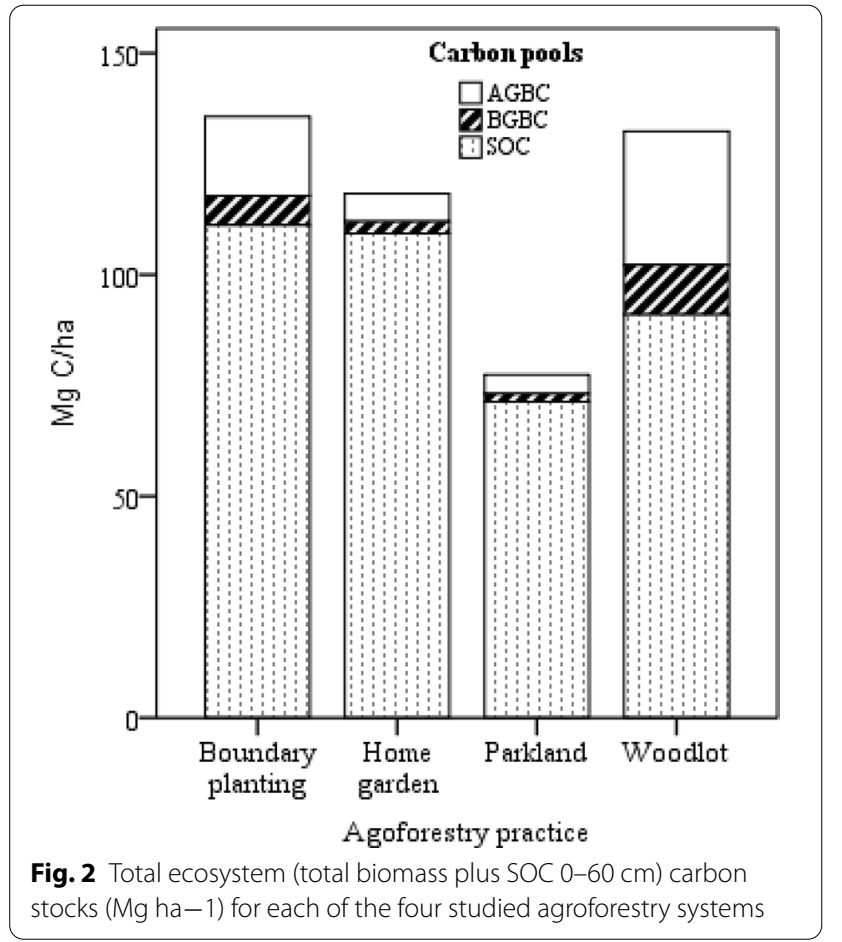

recorded on the woodlot AF practices. The most abundant (number of individual per plot) species in the home garden are Eucalyptus Sps, Olea Africana, and Sesbania sesban; whereas, Faidherbia albida and Ziziphus spina-christi are the dominant tree species of park land AF practices (Appendix 1).

The variation between indigenous AF practices in woody species density, dbh, and height was significant $(\mathrm{p}<0.05)$ (Table 3). Basal areas of the households AF practice ranges from the higher value $\left(17.08 \pm 13.81 \mathrm{~m}^{2} \mathrm{ha}^{-1}\right)$ in the woodlot AF practice to the lower $\left(1.52 \pm 1.89 \mathrm{~m}^{2} \mathrm{ha}^{-1}\right)$ value in the parkland
Table 6 Spearman correlations between biomass, soil carbon stocks, and woody species composition $(n=86)$

\begin{tabular}{lclc}
\hline Carbon stock component & Richness & Abundance & $\begin{array}{l}\text { Shannon } \\
\text { diversity } \\
\text { index }\end{array}$ \\
\hline AGB & -0.192 & $0.308^{* *}$ & -0.202 \\
BGB & -0.192 & $0.308^{* *}$ & -0.203 \\
TBC & -0.183 & 0.333 & -0.197 \\
SOC(depth, 0-60 cm) & $0.291^{* *}$ & 0.025 & $0.351^{* *}$ \\
Total AFC & 0.065 & 0.209 & 0.115
\end{tabular}

AGB: Aboveground biomass; BGB: Belowground biomass; TBC: Total biomass carbon; SOC: Soil organic carbon; Total AFC: Total agroforestry carbon ${ }^{* *} p<0.01$

AF practices. A significantly higher dbh value was recorded on the parkland as compared with the other AF practices (Table 4).

\section{Carbon stock potential}

Mean above and belowground biomass $\mathrm{C}$ stock and SOC stock by layer are shown in Table 5 . Total aboveground biomass $\mathrm{C}$ stock ranged from 2.78 to $21.43 \mathrm{Mg} \mathrm{ha}^{-1}$ in the four smallholdings AF practices. While smallholding total belowground biomass $\mathrm{C}$ stock ranged from 1.26 to $9.70 \mathrm{Mg} \mathrm{ha}^{-1}$. The contribution of above and below-ground biomass carbon stock of the study AF practices varied insignificantly between parkland, home garden and boundary planting while the woodlot was significantly different from home garden AF practices $(\mathrm{p}<0.05)$. The aboveground biomass carbon stock for woodlot was higher by $75,75.4$ and $87 \%$ than a home garden, parkland and boundary planting AF practices. Smallholding total biomass $\mathrm{C}$ stocks ranged between 7.79 and $31.12 \mathrm{Mg} \mathrm{ha}^{-1}$. 
Smallholding SOC stock for the 0-60 $\mathrm{cm}$ layer ranged between 72 and $112 \mathrm{Mg} \mathrm{C}$ ha $^{-1}$ with the $0-20 \mathrm{~cm}$ layer accounting between 39 and $42 \%$ and the $20-40 \mathrm{~cm}$ layer ranged between 27 and $30 \%$ (Table 5). In contrast to biomass $\mathrm{C}$ stocks, mean SOC stocks were highest in the boundary planting $\mathrm{AF}$ $\left(113 \mathrm{Mg} \mathrm{ha}^{-1}\right)$ and the lowest was recorded in parkland $\mathrm{AF}\left(72 \mathrm{Mg} \mathrm{ha}^{-1}\right)$ practices.

Smallholding ecosystem $\mathrm{C}$ stocks ranged from 77 to $135 \mathrm{Mg} \mathrm{ha}^{-1}$ (Fig. 2). The ecosystem carbon stock estimated on the parkland AF was significantly lower than the other traditional AF practices $(\mathrm{p}<0.05)$. The highest ecosystem carbon stock was recorded on the boundary planting and woodlot AF practices. The total biomass carbon stock accounts between 7 and $31 \%$ of the ecosystem carbon stock.

\section{Relationship between woody species diversity and carbon stock}

Total biomass $\mathrm{C}$ stocks were significantly correlated with species abundance (Spearman $r=0.333$; $\mathrm{p}=0.002$ ) but none of the biomass components were significantly correlated to the Shannon diversity index or species richness (Table 6). SOC stock for soil depth $(0-60 \mathrm{~cm})$ were significantly and positively correlated with the species richness and Shannon diversity index (Spearman $\mathrm{r}=0.291 \& 0.351 ; \mathrm{p}<0.01$ ).

\section{Discussion}

\section{Woody species diversity}

We documented high species richness in this sample of indigenous AF systems. This was similar with the species richness found in the Gedeo AF systems of Southern Ethiopia [9], but higher than the species richness found in the AF systems of South eastern Tigray and East Shewa, [23-25], and lower than the South central highlands of Ethiopia [26]. This could be due to environmental variability such as altitude, soils, topography, species adaptability and management strategy [9]. Besides to climatic factors the higher species richness in the lowland might be due to having large land holding size used to retain tree species and relatively lower human population density relative to the midland and highland agroecologies.

As compared to boundary plantings and woodlots, home garden AF demonstrated higher species diversity due to high richness and even distribution of species among small holdings in the highland areas. Similar findings have been reported in other Ethiopian highland areas [27]. The higher species richness observed in home garden is due to the fact that people in the highland areas plant large number of exotic and indigenous tree species in their farmland. Although the species evenness was a highest in midland-home gardens, woody species diversity was highest in parkland AF due to higher species richness and abundance. This is in line with pervious results from South-central Ethiopia [26].

\section{Carbon stock}

From a biophysical point of view, the amount of carbon stored varies between different agroecologies and AF systems [28]. The mean total biomass carbon stock of smallholding farmers was within the range reported for the tropical African AF systems (12-228 t ha ${ }^{-1}$ ) $[29,30]$ and West Africa Sahel $\left(0.7-54 \mathrm{t} \mathrm{ha}^{-1}\right)$ [31] but higher than Kenya and Sri Lanka, respectively [32,33]. Moreover, we find that carbon storage of indigenous AF in Tigray is lower than that of the Gedeo traditional AF system [34] and some systems of the tropics $[35,36]$. This difference is attributable to variation in tree density, site characteristics, management type and variation of the use of biomass estimation models. Similarly, the higher biomass carbon stock found in our study woodlot AF practice was due to a higher number of stems per hectare.

In AF system, soil plays, a vital role in minimizing $\mathrm{CO}_{2}$ concentration in the atmosphere [37]. The SOC stocks in our studies are noticeably high compared to the biomass $\mathrm{C}$ stocks of other AF systems. [38] reported the SOC stocks from Agrisilviculture of Chhattisgarh, Central India is $27 \mathrm{Mg} \mathrm{ha}^{-1}$ on average for of $0-60 \mathrm{~cm}$ soil depth. The SOC stock of the 0-100 cm layer for the Faidherbia albida parkland in Segou, Mali has been reported $33.3 \mathrm{Mg} \mathrm{ha}^{-1}$ [31] and $43 \mathrm{Mg} \mathrm{ha}^{-1}$ for semi-arid Acacia etabica woodland in southern Ethiopia [39]. In contrast, the average SOC stock of our studied AF system was lower than the SOC stocks of the 0-60 $\mathrm{cm}$ layer for tropical forest which ranged from 121 to $123 \mathrm{Mg} \mathrm{ha}^{-1}$ [34]. This variation was due to variation in tree and stand variables (age, crops, tree diversity, composition and tree density), agroecological condition (altitude, climate and wind), soil characteristics (texture, fertility, physical, chemical and biological conditions) and management (fertilization, tillage, residues, land holding size and harvesting regime) $[40,41]$.

The boundary planting and home garden AF practices had the highest SOC stock, while the parkland AF system accounts for the lowest SOC stock. Boundary planting's higher SOC stock is attributable to the presence of herbaceous species and reduced soil 
disturbance relative to parkland. Cultivation of land with a higher level of soil disturbance might cause aggregate breakdown releasing of SOC formerly protected inside soil aggregates [41, 42]. Moreover, herbaceous and belowground fiber roots growing under boundary and home garden AF system contribute to increase carbon input to the soil and the buildup of soil organic matter [43]. In contrast, there is no grass cover in the cultivated land of the parklands; because the herbaceous plants were weeded in winter during soil cultivation and exported during the dry season.

The distribution of $\mathrm{C}$ stocks between soil and biomass varies among ecosystems and with the AF system. Park land accounts for the lowest $\left(70 \mathrm{MgC} \mathrm{ha}^{-1}\right)$, ecosystem carbon stock of the four AF systems, although this figure is higher than the same agroecology of semiarid Zone in Senegal ( $52 \mathrm{Mg} \mathrm{C}^{-1}$ ) [44], in the parkland AF system of western Tigray (47.59 $\mathrm{Mg} \mathrm{C} \mathrm{ha}{ }^{-1}$ ), the exclosures of Tigray region in Northern Ethiopia (61.3 Mg C ha ${ }^{-1}$ ) [45], semi-arid (19 $\left.\mathrm{Mg} \mathrm{C} \mathrm{ha}^{-1}\right)$, sub-humid and humid (21 Mg C ha ${ }^{-1}$ ) and temperate (63 $\mathrm{Mg} \mathrm{C} \mathrm{ha}^{-1}$ ) ecozones [46]. Apart from the recorded high total $\mathrm{C}$ stock, a higher amount of carbon stock was found in the soil of the AF practices. The SOC $(0-60 \mathrm{~cm})$ to total biomass $C$ stock ratio averaged 13.9 for the home garden, 9.2 for parkland, 3.1 for woodlot and 8.4 for boundary planting AF practices. The SOC stock to biomass $\mathrm{C}$ ratio in $\mathrm{AF}$ practices is affected by several factors including the age of the AF system that has been being practiced [47], types of tree species included and rotation age [12, 35], soil type [35], elevation, climatic condition $[48,49]$, and silvicultural management $[45,50]$.

Currently, carbon sequestration and biodiversity conservation are the most fundamental global environmental challenges, particularly in drylands. In the AF systems we examined, there was a negative but insignificant correlation between species richness and abundance on the one hand, and above- and belowground carbon stocks on the other. These results conflict with the positive correlation reported by [51].

We report that SOC stock increases with increasing species richness and Shannon diversity index in all four AF system. This is in keeping with the conventional wisdom that ecosystems with high tree diversity sequester more carbon in the soil than those which have lower diversity [52]. For example, [45] showed that SOC stock positively and significantly correlated with species richness and [53] found that species richness correlated to SOC in the home gardens of Kerala, India. However, the results of our study were in contrast with [51] which found a negative relationship between SOC stock (depth $=0-60 \mathrm{~cm}$ ) and woody species diversity (species richness and Shannon diversity index). These differences might be related with species diversity in the AF system, management practices, age and site factors.

\section{Conclusion}

In addition to the provision of food, the productive and protective function of trees, the Tigray regional state of Ethiopia's indigenous AF practices are critical for the mitigation of climate change and the conservation of tree diversity. Overall, 59 species from 48 genera and 32 families were found in the AF systems we surveyed. Compared to woodlot AF systems, greater species richness was recorded in the home garden and parkland small household AF system. Similarly, we found the highest Shannon diversity and evenness in home gardens. In addition, our analysis shows that, relative to other AF systems, rotational woodlots account for significantly $(\mathrm{p}<0.05)$ greater biomass carbon stock. Second, we found that the method of boundary planting stored the highest total amount of SOC stock, followed by home garden and woodlot $\mathrm{AF}$, respectively. We observed that there is a synergy between SOC stock and woody species diversity (i.e. species richness and Shannon diversity). The ecosystem $\mathrm{C}$ stock of these indigenous AF systems from in the semi-arid zone of Tigray is comparable to, and in some cases substantially higher than, those of tropical forests and other AF systems.

In general, indigenous AF systems have multiple advantages in improving the resilience of small-scale farmers by preserving tree diversity and mitigating climate change. In addition, the increased demand in Ethiopia and other sub-Saharan African countries for fuel wood and timber production, which are the key drivers of deforestation, can be met by indigenous AF systems and practitioners. AF will also contribute to the goal of reducing emissions from deforestation and forest degradation plus (REDD + ) and conservation of tree diversity. 


\section{Appendix 1}

\section{See Table 7.}

Table 7 List of woody species in the indigenous agroforestry system

\begin{tabular}{|c|c|c|c|c|c|c|c|}
\hline \multirow[t]{2}{*}{ № } & \multirow[t]{2}{*}{ Scientific name } & \multirow[t]{2}{*}{ Family } & \multirow[t]{2}{*}{ Local name } & \multicolumn{4}{|c|}{ Number of individuals } \\
\hline & & & & $\mathrm{BP}$ & HG & PL & WL \\
\hline 1 & Acacia abyssinica Hochst.ex Benth. & Fabaceae & Chea & 5 & 8 & 1 & 7 \\
\hline 2 & Acacia etbaica & Fabaceae & Seraw & 2 & - & 253 & - \\
\hline 3 & Acacia polyacantha & Fabaceae & Gomero & - & - & 1 & - \\
\hline 4 & Acacia saligna & Fabaceae & Akacha & 3 & $1-$ & 18 & 2 \\
\hline 5 & Acacia senegal & Fabaceae & Tsifri dimu & - & - & 1 & - \\
\hline 6 & Acacia seyal & Fabaceae & keyih chea & - & - & 123 & - \\
\hline 7 & Acacia sieberian & Fabaceae & Tseada chea & - & - & 13 & - \\
\hline 8 & Acacia torilis & Fabaceae & Karwera & 1 & - & 6 & 3 \\
\hline 9 & Adansonia digitata & Bombacaceae & Dima & - & - & 1 & - \\
\hline $1-$ & Albezia amara & Fabaceae & Sebqana & - & - & 112 & - \\
\hline 11 & Balanites aegyptiaca & Balanitaceae & Mekie & - & - & 2 & - \\
\hline 12 & Boscia angustifolia & Capparaceae & Shisha & - & - & 3 & - \\
\hline 13 & Calotropis procera & Asclepiadaceae & Ghindae & - & - & 4 & - \\
\hline 14 & Carissa spinarum & Apocynaceae & Agam & - & - & 4 & - \\
\hline 15 & Casuarina equisetifolia & Casuarinaceae & Shewshewe & 2 & - & 1 & - \\
\hline 16 & Chamaecytisus proliferus & Fabaceae & Tree lucern & 3 & - & - & - \\
\hline 17 & Citrus aurantifolia & Rutaceae & Lomin & - & - & 1 & - \\
\hline 18 & Combretum adenogonium & Combretaceae & Alenguata & - & - & 2 & - \\
\hline 19 & Combretum molle & Combretaceae & Weyiba & - & - & 81 & - \\
\hline $2-$ & Commiphora habessinica & Burseraceae & Anqwa & - & - & 11 & - \\
\hline 21 & Cordia africana & Boraginaceae & Awhi & 4 & - & 7- & - \\
\hline 22 & Cupressus lusitanica & Cupressaceae & Tsihdi Ferenji & 14 & 4 & - & 8 \\
\hline 23 & Dalbergia melanoxylon & Fabaceae & Zbbe & - & - & 2 & - \\
\hline 24 & Delonix regia & Fabaceae & Diredawa zaf & - & - & - & 1 \\
\hline 25 & Dichrostachys cinerea & Fabaceae & Kenney & - & - & 1 & - \\
\hline 26 & Dodonaoea angustifolia L.f. & Sapindaceae & Tahses & 1 & 1 & - & 1 \\
\hline 27 & Dovyalis abyssinica & Flacourtiaceae & Caito & - & - & 7 & - \\
\hline 28 & Eucalyptus camaldulensis & Myrtaceae & Keyih qelamintos & 13 & 176 & 14 & 9 \\
\hline 29 & Eucalyptus globulus & Myrtaceae & Tsaeda-kelamitos & $5-$ & 369 & - & 115 \\
\hline 3- & Eucleara cemosa & Ebenaceae & Kiliaw & - & - & 6 & - \\
\hline 31 & Faidherbia albida & Fabaceae & Momena & 2 & - & 239 & - \\
\hline 32 & Ficus sycomorus & Moraceae & Sagla & - & - & 1 & - \\
\hline 33 & Ficus vasta & Moraceae & Daero & - & - & 1 & - \\
\hline 34 & Grevillea robusta & Proteaceae & & 1 & - & 2 & 8 \\
\hline 35 & Jacaranda mimosifolia & Bignoniaceae & Yetemenja zaf & 2 & - & 1 & - \\
\hline 36 & Juniperus procera & Cupressaceae & Tse'hedi habesha & 3 & 1 & - & - \\
\hline 37 & Lannea fruticosa & Anacardiaceae & Dgudgun & - & - & 1 & - \\
\hline 38 & Leucaena leucocephala & Fabaceae & Lukina & - & - & 6 & - \\
\hline 39 & Malus domestica & Rosaceae & Aple & 1 & - & - & - \\
\hline 4- & Maytenus senegalensis & Celastraceae & Qebqeb & - & - & 18 & - \\
\hline 41 & Melia azadirach & Meliaceae & $\mathrm{Nim}$ & - & - & 3 & - \\
\hline 42 & Moringa oleifera & Moringaceae & Shiferaw & - & - & 1 & - \\
\hline 43 & Musa paradisiaca & Musceae & Muz & 1 & - & - & - \\
\hline 44 & Olea europaea subsp. Africana & Oleaceae & Awlie & $3-$ & - & 1 & 16 \\
\hline 45 & Ormocarpum pubescens & Fabaceae & Alendia & - & - & 2 & - \\
\hline
\end{tabular}


Table 7 (continued)

\begin{tabular}{|c|c|c|c|c|c|c|c|}
\hline \multirow[t]{2}{*}{ No } & \multirow[t]{2}{*}{ Scientific name } & \multirow[t]{2}{*}{ Family } & \multirow[t]{2}{*}{ Local name } & \multicolumn{4}{|c|}{ Number of individuals } \\
\hline & & & & BP & HG & PL & WL \\
\hline 46 & Osyridocarpus schimperanus & Santalaceae & Qortatimo & - & - & 6 & - \\
\hline 47 & Parkinsonia aculeata & Fabaceae & Shewit hagay & - & - & 6 & - \\
\hline 48 & Populas sps & Salicaceae & Yekibret enchet & 1 & - & - & - \\
\hline 49 & Psidium guajava & Myrtaceae & Zeitun & $1-$ & - & 9 & - \\
\hline 5- & Rhus glutinosa A.Rich & Anacardiaceae & Tetelo & - & - & 2 & - \\
\hline 51 & Schinus molle & Anacardiaceae & Tikur berbere & 2 & 1 & - & 3 \\
\hline 52 & Securinega virosa & Euphorbiaceae & Harmazo & - & - & 1 & - \\
\hline 53 & Sesbania sesban & Fabaceae & Sesbania & 16 & - & - & - \\
\hline 54 & Stereospermum kunthianum & Bignoniaceae & Adgi zana & - & - & 25 & - \\
\hline 55 & Tamarindus indica & Fabaceae & Humer & - & - & 1 & - \\
\hline 56 & unknown & - & Batequa & - & - & 15 & - \\
\hline 57 & Vernonia amygdalina & Asteraceae & Grawa & 5 & - & - & - \\
\hline 58 & Ximenia americana & Olacaceae & Meleo & - & - & 2 & - \\
\hline 59 & Ziziphus spina-christi & Rhamnaceae & Gaba & - & - & 999 & - \\
\hline
\end{tabular}

\section{Abbreviations}

AF: Agroforestry; REDD ${ }^{+}$: Reduce emissions from deforestation and forest degradation plus; C: Carbon; SOC: Soil organic carbon; dbh: Diameter at breast height; AGB: Above ground biomass; BGB: Belowground biomass.

\section{Acknowledgments}

We acknowledge the financial support provided by Ethiopian Environment and Forest Research Institute, Mekelle Environment and Forest Research Centre (MEFRC). The authors acknowledge Tigray Agricultural Research Institute, Mekelle Soil Research Center, Tanqua Abergele, Endamekoni and Kilte Awlaelo District Agricultural Offices

\section{Authors' contributions}

AM \& BT, planned the study, collected data, and prepared the first manuscript, MT, AW \&YG commented the study plan, data analysis and commented and revised the draft manuscript. All authors read and approved the final manuscript.

\section{Funding}

This study was financially supported by Mekelle Environment and Forest Research Center, Ethiopian Environment and Forest Research Institute (EEFRI).

\section{Availability of data and materials}

The datasets used during and/or analyses the current study available from the corresponding author on reasonable request.

\section{Declarations}

Ethics approval and consent to participate Not applicable.

\section{Consent for publication}

Not applicable.

\section{Competing interests}

The authors declare that they have no competing interests.

\section{Author details}

${ }^{1}$ Tigray Institute of Policy Studies, Mekelle, Ethiopia. ${ }^{2}$ Mekele Environment and Forest Research Center, Mekelle, Ethiopia. ${ }^{3}$ Central Ethiopia Environment and Forest Research Center, Addis Ababa, Ethiopia. ${ }^{4}$ Ethiopian Environment and Forest Research Institute, P.O.Box 24536, code 1000 Addis Ababa, Ethiopia.

Received: 24 December 2019 Accepted: 16 April 2021

Published online: 04 May 2021

\section{References}

1. Verchot LV, Noordwijk MV, Kandji S, Tomich T, Ong C, Albrecht A, Mackensen J, Bantilan C, Anupama KV, Palm C. Climate change : linking adaptation and mitigation through agroforestry. Mitig Adapt Strat Glob Chang. 2007;12:901-18. https://doi.org/10.1007/s11027-007-9105-6.

2. Mbow C, Smith P, Skole D, Duguma L, Bustamante M. ScienceDirect Achieving mitigation and adaptation to climate change through sustainable agroforestry practices in Africa. Curr Opin Environ Sustain. 2014;6:8-14. https://doi. org/10.1016/j.cosust.2013.09.002.

3. Ali A, Erenstein O. Climate risk management assessing farmer use of climate change adaptation practices and impacts on food security and poverty in Pakistan. Clim Risk Manag. 2017;16:183-94. https://doi.org/10.1016/j.crm.2016. 12.001 .

4. Bishaw B, Neufeldt H, Mowo J. Farmers'strategies for adapting to and mitigating climate variability and change through agroforestry in Ethiopia and Kenya Forestry C. Forestry Communications Group. Corvallis: Oregon State University; 2013

5. Kuyah S, Öborn I, Jonsson M, Dahlin AS, Muthuri C, Malmer A, et al. Trees in agricultural landscapes enhance provision of ecosystem services in SubSaharan Africa. Int J Biodivers Sci Ecosyst Serv Manag. 2016;12(4):255-73. https://doi.org/10.1080/21513732.2016.1214178

6. Conway D, Schipper ELF. Adaptation to climate change in Africa: Challenges and opportunities identified from Ethiopia. Glob Environ Chang. 2011;21(1):227-37. https://doi.org/10.1016/j.gloenvcha.2010.07.013.

7. Gebrehiwot T, Van Der VA. Farm level adaptation to climate change: the case of farmer 's in the Ethiopian highlands. Environ Manage. 2013;52(1):29-44. https://doi.org/10.1007/s00267-013-0039-3.

8. Hadgu G, Tesfaye K, Mamo G, Kassa B. Farmers 'climate change adaptation options and their determinants in Tigray Region, Northern Ethiopia. Afr J Agric Res. 2015;10(9):956-64. https://doi.org/10.5897/AJAR2014.9146.

9. Negash M, Yirdaw E, Luukkanen O. Potential of indigenous multistrata agroforests for maintaining native floristic diversity in the south-eastern Rift Valley 
escarpment, Ethiopia. Agroforest Syst. 2012;85(1):9-28. https://doi.org/10. 1007/s10457-011-9408-1.

10. Unruh JD, Houghton RA, Lefebvre PA. Carbon storage in agroforestry: an estimate for sub-Saharan Africa. Clim Res. 1993;3:39-52. https://doi.org/10. 3354/cr003039.

11. Lasco RD, Group C, Agricult I, Jane R, Oscar D. Agroforestry systems: Helping smallholders adapt to climate risks while mitigating climate Agroforestry systems: helping smallholders adapt to climate risks. Wiley Interdiscip Rev Clim Chang. 2014;5(6):825-33. https://doi.org/10.1002/ wcc.301.

12. Montagnini F, Nair PKR. Carbon sequestration: an underexploited environmental benefit of agroforestry systems. Agrofor Syst. 2012;61:281-95. https://doi. org/10.1023/B:AGFO.0000029005.92691.79.

13. Nguyen $\mathrm{Q}$, Hoang MH, Öborn I. Multipurpose agroforestry as a climate change resiliency option for farmers : an example of local adaptation in Vietnam. Clim Change. 2013;117:241-57. https://doi.org/10.1007/s10584-012-0550-1.

14. Rosell RA, Gasparoni JC, Galantini JA. Soil organic matter evaluation. In Assessment methods for soil carbon. Lewis Publishers Boca Raton. 2001; 311-22.

15. Snowdon P, Raison J, Keith H, Ritson P, Grierson P, Adams M, et al. National carbon accounting system technical report: Protocol for Sampling Tree and Stand Biomass. 2002; 31:6

16. Blake GR, Hartge KH. Bulk density, In: Methods of Soil Analysis: Part 1. 1986; 1(1): 363-365

17. Magurran AE. Ecological diversity and its measurement. Princeton: Princeton University Press; 1988.

18. Kent M. and PC. BocaRaton:Vegetation description andanalysis; 1992.

19. Kuyah S, Dietz J, Muthuri C, Jamnadass R, Mwangi P, Coe R, et al. Agriculture, ecosystems and environment allometric equations for estimating biomass in agricultural landscapes: I. Aboveground biomass. Agric Ecosyst Environ. 2012;158:216-24. https://doi.org/10.1016/j.agee.2012.05.011.

20. MacDicken K. A guide to monitoring carbon storage in forestry and agroforestry projects. Forest carbon Monitoring Program. Winrock Int Inst Agric Dev. $1997 ; 87$.

21. Pearson TRH, Brown SL, Birdsey RA. Measurement Guidelines for the Sequestration of Forest Carbon. 18th ed. Department of Agriculture, Forest Service: Forest Service, Northern Research Station; 2007. 42 p.

22. IBM Corp. Released. IBM SPSS Statistics for Windows, Version 21.0. 2012.

23. Endale Y, Derero A, Argaw M, Muthuri C. Farmland tree species diversity and spatial distribution pattern in semi-arid East Shewa. Ethiopia For Trees Livelihoods. 2016;26(3):1-16. https://doi.org/10.1080/14728028.2016.1266971.

24. Guyassa E, Raj AJ. Assessment of biodiversity in cropland agroforestry and its role in livelihood development in dryland areas: a case study from Tigray region. Ethiopia J Agric Technol. 2013;9(4):829-44.

25. Mengistu B, Asfaw Z. Woody species diversity and structure of Agroforestry and adjacent land uses in dallo Mena District, South-East Ethiopia. Nat Resour. 2016. https://doi.org/10.4236/nr.2016.710044.

26. Tolera M, Asfaw Z, Lemenih M, Karltun E. Woody species diversity in a changing landscape in the south-central highlands of Ethiopia. Agric Ecosyst Environ. 2008;128(1-2):52-8. https://doi.org/10.1016/j.agee.2008.05.001.

27. Bajigo A, Tadesse M, Res F. Forest research woody species diversity of traditional agroforestry practices in Gununo Watershed in Wolayitta Zone Ethiopia. Forest Res. 2015. https://doi.org/10.4172/2168-9776.10001.

28. Luedeling E, Sileshi G, Beedy T, Dietz J. Carbon Sequestration Potential of Agroforestry Systems in Africa. 2011; (C):61-83. doi: https:/doi.org/10.1007/ 978-94-007-1630-8.

29. Dixon RK, Brown S, Houghton RA, Solomon AM, Trexler MC, Wisniewski J. Carbon pools and flux of global forest ecosystems. Science. 1994;263(20):185-90. https://doi.org/10.1126/science.263.5144.185.

30. Albrecht A, Kandji ST. Carbon sequestration in tropical agroforestry systems. Agric Ecosyst Environ. 2003;99(1-3):15-27. https://doi.org/10.1016/S01678809(03)00138-5.

31. Takimoto A, Nair PKR, Nair VD. Carbon stock and sequestration potential of traditional and improved agroforestry systems in the West African Sahel. Agric Ecosyst Environ. 2008;125(1-4):159-66. https://doi.org/10.1016/j.agee.2007.12. 010.

32. Glenday J. Carbon storage and emissions offset potential in an African dry forest, the Arabuko-Sokoke Forest, Kenya. Environ Monit Assess. 2008;142(13):85-95. https://doi.org/10.1007/s10661-007-9910-0.

33. Mattsson E, Ostwald M. Quantification of carbon stock and tree diversity of homegardens in a dry zone area of Moneragala district, Sri Lanka. Agrofor Syst. 2014;89(3):435-45. https://doi.org/10.1007/s10457-014-9780-8.
34. Lal R. Soil carbon sequestration to mitigate climate change. Geoderma. 2004;123(1-2):1-22. https://doi.org/10.1016/j.geoderma.2004.01.032.

35. Kirby KR, Potvin C. Variation in carbon storage among tree species: Implications for the management of a small-scale carbon sink project. For Ecol Manage. 2007;246(2-3):208-21. https://doi.org/10.1016/j.foreco.2007.03.072.

36. Roshetko JM, Lasco RD, Delos Angeles MS. Smallholder agroforestry systems for carbon storage. Mitig Adapt Strateg Glob Chang. 2007;12(2):219-42. https://doi.org/10.1007/s11027-005-9010-9.

37. Xie TT, Su PX, An LZ, Shi R, Zhou ZJ. Carbon stocks and biomass production of three different agroforestry systems in the temperate desert region of northwestern China. Agroforestry Syst. 2016. https://doi.org/10.1007/ s10457-016-9923-1.

38. Swamy SL, Puri S. Biomass production and C-sequestration of Gmelina arborea in plantation and agroforestry system in India. Agroforestry Syst. 2005. https:// doi.org/10.1007/s10457-004-1999-3.

39. Lemenih M, Itanna F. Soil carbon stocks and turnovers in various vegetation types and arable lands along an elevation gradient in southern Ethiopia. Gederma. 2004;123:177-88. https://doi.org/10.1016/j.geoderma.2004.02.004.

40. Feliciano D, Ledo A, Hillier J, Rani D. Agriculture, Ecosystems and environment which agroforestry options give the greatest soil and above ground carbon bene fi ts in diff erent world regions? Agric Ecosyst Environ. 2018;254:117-29. https://doi.org/10.1016/j.agee.2017.11.032.

41. Marone D, Poirier V, Coyea M, Olivier A, Munson AD. Carbon storage in agroforestry systems in the semi-arid zone of Niayes. Senegal Agrofor Syst. 2017;91(5):941-54. https://doi.org/10.1007/s10457-016-9969-0.

42. Six J, Conant RT, Paul EA, Paustian K. Stabilization mechanisms of soil organic matter: implications for C-saturation of soils. Plant Soil. 2002;241:155-76.

43. Some $A$, Traoré $K$, Traoré $O$, Tassembedo $M$. Potentiel des jachères arti fi cielles à Andropogon spp. dans I ' amélioration des propriétés chimiques et biologiques des sols en zone soudanienne (Burkina Faso). Biotechnol Agronomy Soc Environ. 2007;11(3):245-52.

44. Marone D, Poirier V, Coyea M, Olivier A, Munson AD. Carbon storage in agroforestry systems in the semi-arid zone of Niayes, Senegal. Agrofor Syst. 2016;91:941-54

45. Manaye A, Negash M, Alebachew M. Effect of degraded land rehabilitation on carbon stocks and biodiversity in semi-arid region of Northern Ethiopia. Forest Sci Technol. 2019. https://doi.org/10.1080/21580103.2019.1592787.

46. Schroeder P. Carbon storage benefits of agroforestry systems. Afroforestry Syst. 1994;68:89-97.

47. Li S, Su J, Liu W, Lang X, Huang X. Changes in biomass carbon and soil organic carbon stocks following the conversion from a secondary coniferous forest to a pine plantation. PLoS ONE. 2015. https://doi.org/10.1371/journal.pone.01359 46.

48. Tesfaye M, Negash M. Combretum - Terminalia vegetation accumulates more carbon stocks in the soil than the biomass along the elevation ranges of dryland ecosystem in. J Arid Environ. 2018;155(1):59-64. https://doi.org/10.1016/j. jaridenv.2018.02.004.

49. Soto-Pinto L, Anzueto M, Mendoza J, Ferrer GJ, de Jong B. Carbon sequestration through agroforestry in indigenous communities of Chiapas, Mexico. Agrofor Syst. 2010. https://doi.org/10.1007/s10457-009-9247-5.

50. Nair $\mathrm{V}$, Nair PR. Contribution of trees to soil carbon sequestration under agroforestry systems in the West African Sahel Contribution of trees to soil carbon sequestration under agroforestry systems in the West African Sahel. Agrofor Syst. 2009;1:10-25. https://doi.org/10.1007/s10457-008-9179-5.

51. Negash M. The indigenous agroforestry systems of the south-eastern Rift Valley escarpment, Ethiopia: Their biodiversity, carbon stocks, and litterfall. Vol. 44, Tropical Forestry Reports. 2013.75 p.

52. Lal R, Akinremi O. Physical properties of earthworm casts and surface soil as influenced by management. Soil Sci. 1983;135(2):114-22.

53. Saha SK, Nair PKR, Nair VD, Kumar BM. Soil carbon stock in relation to plant diversity of homegardens in Kerala. India Agrofor Syst. 2009;76(1):53-65.

\section{Publisher's Note}

Springer Nature remains neutral with regard to jurisdictional claims in published maps and institutional affiliations. 